DOI: https://doi.org/10.47264/idea.lassij/4.2.35

Vol. 4, No. 2, (July-December 2020): 453-464

Research Article

URL: https://www.ideapublishers.org/index.php/lassij

\title{
Portrayal of Sayyid Ahmad Barailvi’s Jihad Movement in Pakistani Curricula
}

\author{
Altaf Qadir*1-2
}

1. Department of History, Faculty of Arts and Humanities, University of Peshawar, Peshawar, Pakistan.

2. Institute of Social and Cultural Anthropology, Georg-August-University Gottingen, Germany.

Received: September 22, 2020

Published Online: December 31, 2020

\begin{abstract}
This paper looks into Sayyid Ahmad Barailvi's portrayal in the Pakistani curricula and refers to the factual and contextual errors in textbooks. Most of the 'errors', 'blunders' and 'contextual interpretation' is cited mostly from the sources produced by ideologically inspired writers of the movement. The study analyses his Jihad Movement from an objective distance, and to understand goals of the movement from evidence of its own statements and actions. The syllabus prescribed by Pakistani curriculum wing and textbook boards has presented a generic view of the movement and has avoided the issues associated with those factors which generated opposition from the inhabitants of the area where the movement was launched. In the process, such opposition is associated with 'conspiracies' of the others. These 'textbooks' lack objective analysis of Sayyid Ahmad's three offensives against the Sikhs and eight fights with the local Pukhtuns and Barakzi sardars. He defeated some of his opponents, installed his supporters and replaced many of the old institutions which has not found content of these sources. Apart from institutional amendments, his ideology and religious understanding changed the dogmatic pattern to a great extent. Wars for tribal prestige and honour were replaced by jihad for religious cause.
\end{abstract}

Keywords: Sayyid Ahmad Barailvi, Jihad Movement, Pakistani Curricula, Pakistani Syllabus, Pakistan Studies, Indian History.

\section{Introduction}

The Jihad Movement of Sayyid Ahmad Barailvi (1786-1831) of Rae Baraily was a new experience in the history of South Asian Muslims. An ordinary person with mystic training who founded a movement in the name of Islam. He was an innovative thinker and endeavoured to purify the 'popular Islam' according to his understanding of the 'reformist Islam' during his struggle in the Northern India. However, after his migration to the North-West Frontier, he turned to 'revivalism' aiming at establishing a khilafat on the ideals of the early days of Islam. The movement left multi-dimensional impacts upon Indian Muslims and Pukhtuns of the North-West Frontier.

The Jihad Movement of Sayyid Ahmad has been interpreted by many writers according to their respective understanding and perspective, including his opponents and ideological followers. Much has been written on this movement and its offshoots in Bengal, Deccan, and parts of Northern India (Qeyamuddin, 1979: Qureshi \& Hussain, nd; Butt, nd; Chattopadhyay, 1977; Khan, 1967; Hedayatullah, 1968). Sayyid Ahmad and the Mujahidin have been portrayed 
differently based on their ideological inclination, socio-political background, religious orientation and academic training. These sources may be divided into few categories including the ulama's role in Indian politics or exclusively on Sayyid Ahmad and the Jihad Movement; the North-West Frontier by the foreign visitors, colonial administrators and people of the region; academic works on the North-West Frontier; and Sikh sources.

In the process of making case of the Indian Muslims for a separate homeland, the movement has been narrated in the Pakistani curricula with a specific objective. Therefore, instead of dealing with aforementioned sources, the present paper is focused on the textbooks taught in schools and colleges around Pakistan that are either published by the public institutions or private publishers as per prescribed syllabi by the state institutions. The focus of this paper is finding two errors/fallacies i.e., factual and interpretative in the textbook literature. For this purpose, the prescribed books for Social Studies, Pukhtu and Pakistan Studies from grade 5 to 14 in English Pukhtu and Urdu were examined. However, since the senior level Pakistan Studies books/notes are numerous, their number is more as compared to all others.

\section{Literature Review}

The Jihad Movement is very rich in terms of literature produced on its different aspects. One of the foremost important sources is Waqai (Khan, 2007). The whole Waqai is based on the events of Sayyid Ahmad's life, narrated by those mujahidin who had settled in Tonk after the battle of Balakot (1831). It is mostly comprised of simple narration without involving interpretation, though by the mujahidin who had been active in the Mujahidin Movement and hence emotionally attached. Mihr (1954) has provided a detailed account of the Jihad Movement, his analysis and interpretation. At times it appears as if either he was not aware of the dynamics of the Pukhtun society or he intentionally avoided to consider. Nadvi's (ND) two volumes, is a useful narration of the Jihad Movement of Sayyid Ahmad. He was also an aspirant of the Jihad Movement and was associated with Sayyid Ahmad's family through blood bond. Butt (nd) has written from the perspective of Indian Nationalism and has interpreted the events to support his ideology.

The major academic work exclusively on the Jihad is Ahmad's (1979) doctoral research on the subject. His main focus remained on the aftermath of the Balakot episode (1831). His analysis is important but his discussion lacks knowledge of Pukhtun social dynamics. Ahmad's (1975) work on the movement of Sayyid Ahmad is important as he has consulted numerous sources for his work but the interpretation is little difference from Nadvi's. Hedayatullah's (1968) is one of the best works, especially for those researchers studying the first phase of Sayyid Ahmad's movement, before his migration to the North-West Frontier. Husain's (1957) content and analysis is hardly different from that of Mihr and Nadvi. Qureshi (nd) has allotted considerable space to Sayyid Ahmad and his Mujahidin Movement. He has given a detailed account of the Mujahidin activities after the battle of Balakot and a very good account of the role of the Mujahidin in the First Anglo-Afghan War (1839). The James Settlement Report (1853) and its Supplement prepared in 1865 is a good source of information about the Pukhtun tribes, their ethnographic composition, and inter-clan and state-clan relations. These reports also shed some light on the Sayyid's movement and Pukhtun opposition.

The majority of the previous works on Sayyid Ahmad were written by those who were not familiar with Pukhtun cultural dynamics and who misinterpreted parts of the phenomenon. Some were too biased against the Mujahidin, and others too sympathetic, including Indians 
ideologically inspired by the Jihad Movement. British colonial administrators and writers attributed all disturbances in the North-West Frontier to the mujahidin, and Indian Muslim writers accused the local population of the 'betrayal', as is commonly called, of Sayyid Ahmad.

\section{Theoretical and Conceptual Framework}

The application of potential theoretical frameworks to discussion of the movement of Syyid Ahmad was well-thought-out. The movement at its early stage was a reform movement, though at times it turned sectarian. The focus of the movement remained on the reformation of society; ideally to imitate early Muslim society. In the second phase it turned into a resistance movement; and armed struggle was initiated against the Sikhs. It took yet another turn when the focus of the mujahidin turned to subduing their local opponents and expanding their authority in the North-West Frontier region. Applying resistance and millenarianism theories as discussed by Adas (1979) has limits. His case studies were the movements initiated by locals against the colonial order while Sayyid Ahmad was not inhabitant of area where he took on arms. It is pertinent to note that Sayyid Ahmad knew grievances of Indians due to the founding of the colonial order. Many old aristocratic and religious families were deprived of their previous positions including his own. But his armed struggle in the Frontier was directed against the Sikhs and his local opponents.

The support of the Pukhtuns, may be considered a case of 'millenarianism' and, in Weber's words 'charisma'; and the locals' resistance against the mujahidin may be put in the category of 'Neo-Institutionalism' to follow North (1990). Yet applying 'Neo-Institutionalism' to the Jihad Movement would lead to confusion, as many aristocratic families among the Indians and Pukhtuns adopted themselves according to the requirements of the time, and indeed took advantage from such institutions. Moreover, the mujahidin rose against the Sikhs though new institutions were introduced by the East India Company. Application of 'Messianic' theory as discussed by Shaukat (1993) also bears problems. All components of the movements discussed in his work were not found in the Jihad Movement.

The problem with the application of any theoretical framework is due to the peculiar situation of the North-West Frontier on one hand and the movement, itself, on the other. How will one explain the support and resistance of the Pukhtuns if it is taken as a resistance movement and yet explain why the charisma of Sayyid Ahmad failed to attract Pukhtun support after he introduced his system of administration? It was preferred to focus on an analytical method instead of directly applying any specific theoretical framework. These frameworks, developed in different environments, at times are difficult to apply to historical phenomenon and may lead to distortion of fact-based analysis.

\section{Research Methodology}

A combination of qualitative and analytical methods is applied for the current paper. All sources utilized for the study are available in published form. Most of the sources on the Jihad Movement were those which were written by the ideological inspired writers. The textbooks selected for comparison were those which were published from different cities in Pakistan but available in markets of Khyber Pakhtunkhwa. To evaluate "historical facts" based on available data, analytical and descriptive methods have been applied. The content analysis method has been used to analyze the collected data. 


\section{The Jihad Movement in Textbooks Content: Analysis and Discussion}

Most of the textbooks, taught at public and private institutions, link the Jihad Movement with Shah Wali Ullah. It has been explicitly narrated 'he [Sayyid Ahmad]continued the reform movement of Shah Wali Ullah' (Humera et al., 2006: 79); 'Shah Wali Ullah's movement had promoted the spirit of Jihad in the coming generation' (Kazmi, 2006: 28); Mujahidin Movement was the 'result of the teaching of Hazrat Shah Waliullah' (Khan, 2012: 43). And 'hundred years after the start of Shah Wali Ullah, Shah Ismail gave his blood to revive his grandfather movement' (Khan, nd: 72-74). We understand that though Sayyid Ahmad's thought was partially shaped by Shah Wali Ullah tradition but his strategy and initiative was totally different. Shah Wali Ullah was dedicated to scholastic writing instead of personal involvement in political activities. His political activities were limited to writing letters to different Muslim princes and nobles. Furthermore, Shah Wali Ullah remained in Delhi during his life time and there is no credible evidence to suggest that he preached the tenets of Islam or Jihad in-person.

Sayyid Ahmad's career and strategy were different in this regard. Sayyid Ahmad was not a scholar like Shah Wali Ullah. He started his career as a soldier, abandoned his employer and turned a 'reformer'. Before his migration to the North-West Frontier, his entire career as a reformer was occupied with preaching tours. He performed Hajj in the companionship of hundreds of people which itself was exemplary He preached Jihad, became leader of the movement and laid down his life for this noble cause. Rizvi finds no historical connection between jihad movement of Sayyid Ahmad, Shah Abdul Aziz and Shah Wali Ullah. The theories of traditional and modern scholars that transform Shah Wali Ullah and Shah Abdul Aziz into revolutionaries, is unfortunately undocumented (Rizvi, 1982: 531).

Another problem in these textbooks is related to motives and objectives of Sayyid Ahmad. These writers either lack interests in finding the facts about Sayyid Ahmad's objective or have intentionally tried to trivialize his role. They usually refer to Sikhs' brutalities while discussing the start of Jihad movement. For instance, 'the Sikhs, rulers of the Punjab, treated Muslims with cruelty and were not given religious freedom' (Humera et al., 2006: 79); 'the Sikh Raja was the biggest enemy of the Muslims, who had turned lower portion of one of the mosques in Peshawar into stable for horses and in the upper portion he had built toilets' (Aqeel, nd: 95) and that the 'Sikhs were committing cruelties on their Muslim subjects in the Punjab' (Awan, nd: 53). Some sources have given detailed accounts of these brutalities i.e., 'the Sikhs had turned mosques and shrines into temples and stables, had forbidden Azan-call for congregation prayers, and frequently interrupted the religious practices of the Muslims' (Rabbani, 1998: 42-43) and that 'Sayyid Ahmad send Shah Ismail to Punjab for inquiry and he upon his return, narrated the details of the brutalities of the Sikhs on the Muslim population of the Punjab' (Siddiqi, nd: 45). One writer has limited the 'fundamental aim' of his movement 'to contain the Sikhs and restrain them to pursue their anti-Muslim agenda' (Khan, 2012: 43) Only one source has referred to the broader objective of the Jihad movement that Sayyid Ahmed 'saw the terrible state of the Muslims in the subcontinent and started a movement to establish the government of Muslims once again, which they had lost after the Mughal Empire' (Aqeel, nd: 95).

We understand that the jihad of Sayyid Ahmad was inspired by the teaching of the Qur'an and ahadith - traditions of the Prophet Muhammad (Peace Be Upon Him). We, however, cannot 
overlook the political situation of the subcontinent in his time which augmented the spirit for armed struggle against those who had been establishing their rule and principalities on the edifice of the crumbing Muslim empire. The Muslims were distressed with their dilapidated political and social status due to western imperialism. India's centuries old institutions were being replaced by the colonizers. Sayyid Ahmad's movement was neither aimed at containing Sikhs only nor to cease the turning of mosques to toilets and stables. In fact, he aimed much higher at over throwing Sikhs and ousting English from India. Confronting Sikhs first was due to several reasons which have been written elsewhere (Qadir, 2014).

Going through the different elements of the Movement, we find intentional or unintentional distortion of facts. For instance, 'Sayyid Ahmad was an ex-alumnus of Madrassa Rahimia;' and 'in compliance with the orders of his mentor, he along with his eight colleagues proceeded to Makka to perform Haj' (Khan, 2012: 43) the 'Mujahidin defeated Ranjit Singh in Hazro' and 'Sayyid Ahmad established his government in Peshawar and its outskirts' or 'the increasing power of Sayyid Ahmad compelled the chieftain of Bakarzai tribe to join him' (Humera et al., 2006: 79). And for that matter, 'Sayyid Ahmad prepared his army, took it to Peshawar, declared Jihad against the Sikh Raja, attacked the city and established an Islamic government in Peshawar, on 11 January 1827' (Aqeel, nd: 95). Regarding their number, one source has narrated that Sayyid Ahmad 'arrived at Kabul in the company of seven thousand Hindustani Muslims' (Siddiqi, nd: 45) and that he was 'joined by Yar Muhammad Khan and other prominent pathan leaders like Pir Hakman Khan’ (Rabbani, 1998: 44).

Some sources contain not only factual errors but have also changed the approach of Sayyid Ahmad's battles. It has been narrated that Sayyid Ahmad declared 'his Jihad against the Sikhs and conducted successful Ghazwat' or 'he could not succeed as the Sikhs and few chiefs of Peshawar were against them' and interestingly the 'English destroyed the centres of the Mujahidin in Naranji, Panjtar and Chinglai. Many people were killed by the English troops in Mangal Thana, Sithana, Malka, Chamla and Ambela and burnt the settlement' Tarin et al., nd: 23-24). And above all 'since Sayyid Ahmad had over thrown a Sikh ruler, Sikhs became his enemy and he had to fight them for several years and conquered Hazara and Mardan (Aqeel, nd: 95). A senior level book, published by an international publisher, is alarmingly against the historiographical facts by stating 'Sayyid Ahmad sought the Maratha assistance on the surety to Maratha chief Maharaja Daulat Rao Sindhia during their meeting in 1828 that he would reestablish their rule in case of his success', he 'took inspiration from Makkah' and he 'followed his reform movement in the Frontier which turned the local chieftains against him.' Sayyid Ahmad was 'defeated in the battle of Saidu Sharif' and that 'they were able to establish their cantonment at Peshawar in 1830' (Kazmi, 2006: 48) and 'Sayyid Ahmad and Shah Ismail were martyred and their tombs are in Balakot' (Siddiqi, nd: 48). And interestingly 'Sikhs popularized that Sayyid Ahmad was a Wahabi. Many Afghan chiefs left Sayyid Ahmad company, revolted and assassinated his quza and tax collectors' (Siddiqi, nd: 49).

We argue that Sayyid Ahmad was neither an alim in the technical meaning of the term and none of sources on Sayyid Ahmad or Jihad movement has declared him an alumnus of Madrassa Rahimia. All historical accounts assert that Sayyid Ahmad had performed Haj in the company of several hundred people and not only eight colleagues. Moreover, he performed Haj not on his mentor's advice, rather his personal initiative. Sayyid Ahmad and Ranjit Singh never encountered each other in the battlefield or table talk. The term ghazwat is used for the battles against the Sikhs. Though, ghaza in Pukhtu poetry refers to any battle against the 
infidels but textbooks for academic purpose should use the appropriate term i.e., battles/fights. Technically, ghazwat were battles in which the Prophet Muhammad (Peace Be Upon Him) participated (Your Dictionary, nd). It is appropriate to state that the Mujahidin's settlements were destroyed after their failure in the War of Independence (Qadir \& Altaf, 2014). Sayyid Ahmad had not over thrown any Sikh ruler. Parts of Hazara were taken from Painda Khan, ruler of Amb, while Mardan was taken from Ahmad Khan; none of whom were Sikh. Moreover, Sayyid Ahmad had not sought Marathas assistance on the promise of re-establishing their rule, rather, Daulat Rao was assured that his movement was not aimed at uprooting the existing princes in power. Sayyid communicated through letters to different princes including Sindhia that his objective was liberating sub-continent from the foreign yoke and to handover the reign of its government to whom it was due (Thanesari, 1969). Furthermore, they had not met in 1828, rather it was in 1826 during the Sayyid's migration to the Frontier.

Sayyid Ahamd's initial inspiration for the movement from Makkah has not been authenticated from credible sources. It is evident from many sources that he had made considerable preparation for Jihad before performing Haj (Mihr, 1954; Khan, 2007). Sayyid Ahmad did not follow his reform mission after his migration to the frontier, instead he became a revivalist and imposed the Islamic commandments according to his understanding of Islam. Sayyid Ahmad was defeated in battle of Shaidu, not Saidu Sharif. The Mujahidin had not established any cantonment in Peshawar rather they restored Peshawar and left for Panjtar after staying for three weeks only. None of the authentic sources suggest that Sayyid Ahmad ever confronted Ranjit Singh. The attack on Hazro was an unexpected night attack and many ideologically inspired writers disassociate Sayyid Ahmad and Mujahidin from the incident. The assertion that Sayyid Ahmad defeated the Sikhs in the city of Peshawar and established his government in the city and its outskirts in January 1827 is not factual. Neither Peshawar was in the jurisdiction of Sikhs before 1834, nor did Sayyid Ahmed defeat them in the city. Sayyid Ahmad had established his government in parts of the present districts Swabi, Mardan, Buner and Haripur after the second oath in February 1829 (Qadir, 2014: ch. 5; Khan, 2007: 1434-50; Mihr, 1954: 524-27).

The Mujahidin who travelled from India were not more than 600 and during the entire sojourn of Sayyid Ahmad, their number did not exceed 1100. We did not find any 'prominent pathan leader with the name of Pir Hakman Khan. Some factual errors reflect the negligent attitude of the textbook writers. For instance, using 'Bakarzai' in both English and Urdu versions, instead of Barakzi (Humera et al., 2006: 79). Similarly, 'Yar Muhammad Khan was the grandson of Ahmad Shah Abdali' (Siddiqi, nd: 49) is historically inaccurate as Yar Muhammad Khan had no blood relation with Ahmad Shah Abdali family. The former was Barakzi while the later was Sadduzi. Ranjit Singh's visit to Peshawar during 1826-31 is also not evident from historical sources. Moreover, Sayyid Ahmad had initiated his fight against the local chief's way long ago. He united the ongoing tarboorwali (enmity between cousins) and had supported one party against the other. Yar Muhammad Khan, no doubt had no affiliation with the people of the Yusafzi area. He was against Sayyid Ahmad for obvious reasons and had resorted to arms against the Mujahidin when Khadi Khan was assassinated and his brother sought support of Yar Muhammad Khan. Yar Muhammad Khan died of the wounds he received in the battle of Zaida (Khan, 2007: 1434-50; Mihr, 1954: 524-27) that subsequently led to the appointment of Sultan Muhammad to the seat of Peshawar.

When Sayyid Ahmad took over Peshawar in October 1830, he restored it to Sultan Muhammad Khan after three weeks. He had promised to implement sharia wholeheartedly (Khan, 2007: 
1987-88; Mihr, 1954: 659; Ahmad, 1975: 250-51). Siddiqi had declared that the blunder was not taking promise from Sultan Muhammad Khan. Although, we assert that the blunder was his appointment. Social 'reformation' and modifying Pukhtuns' traditions had started much earlier and that's too by using force. Objectively speaking, Sultan Muhammad Khan had no sympathies with the tribes ${ }^{1}$ of Peshawar vale. Although neither was, he an agent for Sikhs' nor assassination of the Mujahidin was a Sikhs' conspiracy. Sultan Muhammad Khan and the tribal chiefs assassinated the Mujahidin agents themselves for different reasons including the high handedness of the latter. The split in Mujahidin at this stage is contrary to the facts. All the remaining Mujahidin migrated to Nandihar valley and none left for their respective homes. The split among them was witnessed much earlier at the question of khialafat when Maulvi Mahbub Ali had left Sayyid Ahmad along with a considerable group of the Mujahidin (Nadvi, nd: 57). Shah Ismail's tomb is in Balakot but we assert that Sayyid Ahmad tomb was destroyed and his dead body was thrown into the river by the Sikh troopers, which was never recovered.

Siddiqi's assertion that Sayyid Ahmad was popularized as Wahabi by the Sikhs is also not testified by credible sources. Sayyid Ahmad's followers were dubbed Wahabis by the English writers to minimize the sympathies of the fellow Indian Muslims who were contributing financial aid and men to the movement. The Sikhs, on the contrary, were ignorant of the delicate nature of Islam, popular Islam and reformist Islam. Sikhs encounter with Sayyid Ahmad's Mujahidin was brief in which the former relied on their arms and local diplomacy instead of long-term policy implication like the Western Colonizers. We could have observed a better resistance of Sikhs to the English colonizers if Sikhs were mature enough to formulate long term policies.

Spreading Islam through preaching is the full fledge portfolio of Islam and its role cannot be trivialized. Sayyid Ahmad himself, though contended to wage jihad, knew its importance and had sent missions to mainland India for this purpose. The writers of these text books might have intentionally or unintentionally tried to distort facts for promoting a certain view point under the patronage of stakeholders. Nonetheless, the interpretation of his Jihad movement's objective and strategy needed some clarification. 'Sayyid Ahmed believed that the major reason for the Muslim downfall was forgetting the fundamental principles of Islam, particularly the spirit of jihad. He revived the spirit of jihad in Muslims;' (Aqeel, nd; 95) he 'roused the Muslims to jihad' and 'many brave and good people joined him;' (Awan, nd: 53-54). The purpose of his life and struggle was not confined to the spread of Islam by preaching only, but he believed in taking practical steps for this purpose. Sayyid Ahmad aimed to establish a State which was based on Islamic principles' (Rabbani, 1998: 42).

It is interesting to note that since colonization of the Muslim world by the western countries, all religious circles consider an Islamic state as the only way out from the present crisis. Contrarily, historical data suggest that the strategy needs reconsideration as it did not help the Muslims in last 200 years where billions are spent and millions perished. The establishment of an Islamic state being the main objective of the movement is doubtful. The literature referred here indicates that he was not clear about his 'main objective' and decided it soon after attack on Hazro. We assume that he was indecisive and that has been evident by his random decisions such as declaration of Imarat, change of centres, endeavours in Kashmir and migration to Nandihar valley after the assassination of Mujahidin in Peshawar valley (Qadir, 2014: Ch. 3). No doubt he was accompanied by many good and brave men but among them were many criminals. Abdul Hamid Khan, the risaldar of Mujahidin, who was killed in the battle of 
Mardan, was a symbol of all vices of the day before his migration to the North-West Frontier (Ahmad, 1975: 241-45; Khan, 2007: 1813-45).

The establishment of an Islamic government by Sayyid Ahmad has always been idealized beyond facts. A source narrates, 'they established an Islamic government, appointed quza resolved disputes according to Quran and Sunnah. They waged jihad exactly under the principles which are unique for fighter in the path of Allah against the worldly warriors. They followed the civilized principles of war and committed none of the brutalities. Their force contained neither liquor and women nor music. Their camps did not turn brothels. Their fighters spent their day on the horses back and their nights in offering prayers. They neither proved coward in case of defeat nor turned proud in case of victory. The pure Islamic jihad in India was neither fought before them nor after. The small tract of land which they ruled for a short time was an exact replica of the khilafat in the footsteps of Prophethood-same humble imarat, same equality, same shura, same justice, same Islamic hoodud. They established such a rule which was a true replica of the rule of Siddiq (RA) and Umar (RA)' (Khan, 2012: 73). He also introduced social reforms and asked the local people to abandon their old customs and life patterns. He urged them to adopt Islamic way of life and refrain from taking intoxicants (Rabbani, 1998: 44-45). The above narration needs objective content analysis.

Quza were appointed for resolution of disputes but two problems emerged: None of the Quza was local except Mulla Said Ameer. The appointment of Quza disabled the centuries old institution of jargah. No doubt the Jihad Movement was a naïve experience in the Indian subcontinent but it was not adopted exactly according to Islamic principles. We have ample evidences suggesting Sayyid Ahmad and his Mujahidin clearly went against the principles of Islam. Firstly, Sayyid Ahmad sent letter to Ranjit Singh to invite him to Islam but attacked the Sikhs before response from Ranjit Singh (Mihr, 1954). Secondly, the Mujahidin kept Khadi Khan in dark about his future and was assassinated in a surprise night assault. Thirdly, after assassinating Khadi Khan, his family was kept as hostages, (Mihr, 1954) which was definitely against the Islamic principles. Exemplifying Sayyid Ahmad khilafat with that of Abu Bakr (RA) or Umar the Great (RA) is against facts. The Prophet Muhammad (Peace Be Upon Him) and his immediate successors did not disregard the prevailing tribal structure in which they lived, rather respected it. Indeed, the khilafat established by them was almost replica of the Arab tribal structure with minute alteration. Moreover, Shah Ismail had told the Hassanzi tribesmen, who had sought exemption from ushar, that even Amir ul Mominin had to pay ushar if he grows crops. Although, practically, there is no reference to the payment of ushar on the crops grew by the Mujahidin during their sojourn in parts of Amb. We agree to the extent that 'Islamic State' was established and public were to strictly adhere to the basic principles of sharia according to the Mujahidin's interpretation of Islam.

Whilst discussing the failure of Jihad Movement, there are ample references to establish that much of the facts are misleading. Few of the instances are: 'the Mujahidin could not succeed as the Sikhs and few chiefs of Peshawar were against them' (Tarin et al., nd: 24); 'by seeing the increasing power of Sayyid Ahmad, the chieftain of Peshawar joined Sikhs and made conspiracy against him' (Humera et al., 2006: 79) or but the 'enemy hatched conspiracies with local leaders and defeated them' (Awan, nd: 54). Ironically, even at a senior level, a book published by an international publisher has distorted facts in a more bold fashion which writes 'the Pukhtuns considered his reformation as fanaticism', hence 'Sayyid Ahmad had to fight against the Sikhs and local Muslim chieftains alike' and that 'the Muslims were defeated in the battle of Saidu Sharif as the Sikh commander Budh Singh had conspired with the local 
chieftains' (Kazmi, 2006: 29) and 'the treachery of own people resulted in the victory of the enemy' (Khan, 2012: 73). Siddiqi has attributed assassination of the Mujahidin to the Sikhs' conspiracy (Siddiqi, nd: 49). Another widely referred source book in many colleges across Khyber Pakhtunkhwa while discussing the failure of the movement also refers to the Sikhs' conspiracy along with British dubbing Mujahidin as Wahabis, Nikah-e Bewagan-widows remarriage, shortage of weapons with the followers of Sayyid Ahmad and the last but not the least the financial constraints which resulted in Mujahidin's defeat at Peshawar (Khan, 2012: 44-45). One may find details of failure somewhere else (Qadir, 2014: Chap. 6), we are unable to agree with the argument of Sikh conspiracy. Referring to the conspiracy of the 'others' is an old tradition among South Asian Muslims. It intends to give an impression that we are all alright but the 'enemy' does not leave us to live with peace. The main stream popular media, religious right wing and Pakistani establishment usually refer to such 'conspiracy theories' instead of confessing institutional and individual failure.

The Sikhs, being at war with the Mujahidin could use every possible mean to achieve their objective and vice versa. The term fanaticism, as referred by Kazmi does not seem accurate. The Pukhtun opposed the Mujahidin due to their display of disregard and ignorance for the local social fabric and political economy. We understand that any alien force (state or nonstate) interferes with the tribal structure without their consent, it not only damages the structure but its own entity. The British dubbing of Mujahidin as wahabis contributing towards their failure in Peshawar (Khan, 2012: 45) is historically against facts. They were dubbed wahabis but only after British occupation of the North-West Frontier. Widows' remarriage, as referred by Khan (Ibid.) is equally against facts. Sayyid Ahmad himself, while addressing a gathering at Shawa has stated that marrying off widows was not a problem in Pukhtuns as they were accustomed to it. Rabbani's assertion about the failure of movement is valued when he states that the movement extremely lacked organized leadership after Sayyid's death (Rabbani, 1998, 45). Siddiqi's view seems a mere assumption that 'Mujahidin implemented sharia immediately after their success in certain areas. Pathans have adopted many wrong traditions under the Hindus' influence. Furthermore, it has been reported that Mujahidin Movement failed due to 'none cooperation of Amir of Kabul which was expected' and lack of financial resources' (Siddiqi, nd: 49-50).

We are unable to digest that the Pukhtuns had adopted 'wrong' traditions under the influence of Hindus, who were neither their rulers nor had majority in the area. Expecting cooperation from the Amir of Kabul was not prudent for Sayyid Ahmad. Afghanistan was going through transitional phase and the numerous Barakzi brothers had divided the country in to small principalities. Moreover, Sadduzi, claimants of the throne, despite their many failures expected their prospects. Sayyid Ahmad had personally witnessed their warring state during his journey through Afghanistan. We assert that the Pukhtuns' opposition to Sayyid Ahmad was due to his decision to replace the centuries old tribal set up and family traditions (Chand, 1967: 26), his hasty decisions, use of force in imposing rigid ideas on unwilling public (Mallick \& Mallika, 1977: 124) and marriage of their daughters to outsiders or to their fellow tribesmen without a dowry (James, 1865: 47). These books writers could safely write that the Pukhtuns opposed the Mujahidin due to some of their policies which the local considered interference in their social fabric and political economy.

While discussing the consequences of the Jihad Movement, the textbooks promotes a certain ideology and leave the young lot vulnerable to the agendas of state agencies and non-state 
actors. We want to draw the attention of readers to the assertions of different sources. It has been stated that 'but the spirit of jihad did not finish' (Tarin et al., nd: 24) 'the movement failed for the time being but it created a new zest among the Muslims' (Humera et al., 2006, 79) and he laid down his life to 'gain freedom for the Muslims and that is why today his name is written in golden letters among the martyrs' (Aqeel, nd, 96) and they 'left the spirit of armed struggle behind them which is still active' (Kazmi, 2006: 29). Furthermore, 'Sayyid Ahmad revived the spirit of jihad in a declining Muslim society.' The leaders of the Jihad Movement worked 'against the prevailing shirk - polytheism, bida'at - innovations, and reformed the beliefs and practices of the Muslims.' And 'the impact of jihad and qital was the war of independence of 1857.' 'This spirit later worked during Khilafat Movement and Pakistan Movement.' The Mujahidin Movement resulted in the 'establishment of Deoband Seminary which played unprecedented role in keeping alive the Islamic fields of knowledge and traditions.' The objective of Mujahidin was to 'eliminate the English Imperialism and establish the rule of the Muslims which were achieved with the creation of Pakistan in 1947.' 'The sacrifices of the Mujahidin which continued for more than a century did not go waste' (Khan, 2012: 76). 'The Jihad Movement did not die after the defeat at Balakot. Some of his disciples struggled to continue the movement and were successful to certain extent' Rabbani, 1998: 45). The Jihad Movement temporarily failed but 'it revived the spirit of liberation among the Muslims which resulted in the creation of Pakistan. History indicates that these Mujahidin participated and showed their bravery in War of Independence 1857, Anglo-Afghan War, Silk Handkerchief Movement and Khilafat Movement' (Siddiqi, nd: 51). Khan asserts that the 'Mujahidin Movement produced great results in the shape of Faraizi Movement and the War of Independence; and supplemented new magnitude to the socio-political and religious histories of the Indian Muslims' (Khan, 2012: 45).

We would like to analyze the above extracts through various sources. The revival of jihad has been associated with Sayyid Ahmad to the extent that almost every militant organization links itself with him. We may term them 'self-proclaimed ideological inspired' but the youth are taught the phenomena in this manner. No doubt Jihad Movement has a long-standing impact on the entire region but it needs proper context. Sayyid Ahmad was first person who persuaded his agenda and challenged the social structure and political economy of the area. The appointment of quza-judges minimized the role of jargah and the appointment of tahsildars - tax collectors eliminated the role of traditional Pukhtun leadership. He took all actions in haste without proper homework and considering the ground realities. On one hand it resulted in alienating a certain section from religion and making religious ideologue on the other. This 'new institutionalism' has been followed by all successive governments in the area. The British government altered the traditional institutions and introduced new one. After the creation of Pakistan, the same pattern was followed which instead of integration of the state of Pakistan, accelerated disintegration. People are alienated due to the unrealistic policies of the state managers. The short sightedness of Sayyid Ahmad by dubbing his opponent as rebels and traitors has successfully followed by the state and non-state actors in the same way. Difference of opinion was not tolerated by Sayyid Ahmad, followed by the Pakistani state institutions and all classes irrespective of their rightist or leftist tendencies. Moreover, we are unable to find ample evidence regarding the role of Mujahidin Movement in Silk Handkerchief Movement, Khilafat Movement and Pakistan Movement.

\section{Conclusion}

Most of the literature on the Sayyid and his Mujahidin Movement is written from a subjective 
perspective. Majority of the writings reflect two opposing perspectives: firstly, the ideologically inspired writers who declare the Mujahidin as pious souls and idealize all their thought and actions. These include the Pakistani State sponsored textbooks, main stream popular media, newspapers, periodicals and literature produced by religious groups especially the Deoband School of thought and the militant organizations including former Jaish-eMuhammad, Harkat-ul-Ansar, Lashkar-i-Tayyaba and alike. The second group of authors that oppose religious thought including the Barailvis who always dub Sayyid Ahmad as an English agent and denounce his beliefs. Interestingly both schools of thought have agreement up to Shah Wali Ullah.

Textbook and/or the books not prescribed as textbooks but consulted as source material rarely contain objective stuff. Subjectivity in historical writings cannot be eliminated at any level but it can be minimized with proper realization of one's religious orientation, social background, economic status, political affiliation and academic training. Syllabus has always been used by state agency for its agenda. The textbook writers rarely put efforts to find the facts. Instead, they write what raw knowledge they have. In certain cases, the state agency plays it role and direct the writers to describe some facts in a certain way. The state agency and at times nonstate actors, through pressure groups and lobbies pursue their respective agendas. The citizen of any entity may not object if the agenda is not against to their entire interests. The Pakistani curricula have been under change for state and its managers' interests since Noor Khan's commission. Every successive government has altered the basic facts for pursuing its respective agendas. The armed movement of Sayyid Ahmad got main stream popularity since mid-1970s when the state agency needed religious 'ideologue' for its agenda. Not commenting on the validity of the 'agenda' we assert that facts are distorted and heaps of lies were created in the name of history. Objectivity was vanished and a 'confused nation' is created who is still debating the very creation of the State.

The researchers and academics need to come forward and start writing in their respective fields of specialization for a common reader too. Academic writing in English language is our requirement but being citizen of the state where one lives by default or by choice, one owes much to the poor taxpayers. We need to educate the citizens in popular language through popular means. The transformation, through indigenous and evolutionary process usually brings positive results compared to engineered and state-oriented agendas, when pursued with force always brings destruction to the traditional, state and religious institutions.

\section{References}

Adas, M. (2012). Prophets of Rebellion: Millenarian Protest Movements against the European Colonial Order. UNC Press Books.

Ahmad, M. (1975). Saiyid Ahmad Shahid: His Life and Mission. Academy of Islamic Research and Publications.

Aqeel, F. (nd). Social Studies Class 5. New Century Education.

Awan, A. A. (nd). Social Studies Class 7. Gaba Educational Books.

Butt, Z. D. (nd). Shah Waliullah ka Qafila. Idara Adab-e-Atfal.

Chand, T. (1967). History of the Freedom Movement in India, vol. II. Ministry of Information and Broadcasting, Government of India.

Chattopadhyay, D. K. (1977). The Ferazee and Wahabi Movements of Bengal. Social Scientist, 6(2), 42-51. https://doi.org/10.2307/3516683 
Hedayatullah, M. (1968). Sayyid Ahmad: A Study of the Religious Reform Movement of Sayyid Ahmad of Ra'e Bareli. Master of Arts Thesis, Department of Islamic Studies. McGill University. https://escholarship.mcgill.ca/concern/theses/hq37vs57f

Humera, K. M. \& Murad, S. (2006). History Class 7. Khyber Pakhtunkhwa Textbook Board. Husain, M. (Ed.). (1957). A History of the Freedom Movement: 1707-1831 (Vol. 1). Pakistan Historical Society.

James, H. R. (1865). Report on the Settlement of the Peshawar District. Dependent Press.

Kazmi, M. R. (2006). Mutalea' Pakistan (Urdu tr.). Sayyid Saeed Ahmad. Oxford University. Khan, A. Q. (nd). Mutalea' Pakistan. A. H. Publishers.

Khan, M.A. (1967). Tariqah-i-Muhammadiya Movement: An Analytical Study. Islamic Studies, 6(4), 375-388.

Khan, N. (2012). Pakistan Studies and Pakistan Affairs. Postgraduate Department of Pakistan Studies, Islamia College University.

Khan, N. M. W. (2007). Waqai Sayyid Ahmad Shahid. Sayyid Ahmad Shahid Academy.

Mallick, A. R., \& Mallika, E. A. (1977). British policy and the Muslims in Bengal, 1757-1856. Bangla Academy.

Mihr, G. R. (1954). Sayyid Ahmad Shahid. Sheikh Ghulam Ali.

Nadvi, A. H. A. (nd). Sirat-e-Sayyid Ahmad, vol. II. Dar al-Isha'at.

North, D. C. (1990). Institutions, institutional change and economic performance. Cambridge University.

Qadir, A. (2014). Sayyid Ahmad Barailvi: His Movement and Legacy from the Pukhtun Perspective. SAGE.

Qadir, A., \& Atlas, S. (2014). The War of Independence 1857 and the North-West Frontier: The Struggle of the Mujahidin against the English. Pakistan Historical Society. Journal of the Pakistan Historical Society, 62(1), 7-19. https://www.proquest.com/openview/baadd6dccd4c483c093364c90f9d9dad/1?pqorigsite $=$ gscholar\&cbl $=646551$

Qeyamuddin, A. (1979). The Wahabi Movement in India. National Book Foundation Pakistan. Qureshi, I. H. (nd). Ulema in Politics. Al-Ma'arif.

Rabbani, M. I. (1998). A Comprehensive Book of Pakistan Studies (2 ${ }^{\text {nd }}$ ed). The Caravan Book House.

Rizvi, S. A. A. (1982). Shah' Abd Al-'Aziz: Puritanism, Sectarian, Polemics and Jihād. Ma'rifat.

Siddiqi, A. G. (nd). Mutalea' Pakistan. Classic Publishers.

Shaukat, A. (1993). Millenarian and Messianic Tendencies in Islamic History. Publishers United.

Tarin, G. F. M., Hasrat, M. Z., \& Wahab, F. (nd). Pukhtu Class 8. Khyber Pakhtunkhwa Textbook Board.

Thanesari, M. J. (1969). Maktubat-e-Sayyid Ahmad Shahid aur Kala Pani. Nafees Academy. Your Dictionary. (nd). Ghazwa Meaning. http://www.yourdictionary.com/ghazwa

Note:

${ }^{1}$ We are not using the term tribe and tribalism in its colonial connotation rather the classical literature and folklore is evident of the term Olas, qam and qabila - tribe in its local context. 